\title{
THE FORMATION OF HETEROGENEOUS STOREYS IN THE CAMBIUM ON THE EXAMPLE OF Laburnum anagyroides Medik
}

\author{
Anna Wilczek \\ Botanical Garden, Centre for Biological Diversity Conservation of the Polish Academy of Sciences, \\ Prawdziwka 2, 02-973 Warsaw 76, Poland \\ e-mail: a.wilczek@vp.pl
}

Received: 10.12.2011

\begin{abstract}
The formation of the storeyed pattern of cambium in the first two years of cambial activity and the structure of mature cambium was examined in Laburnum anagyroides, a decorative shrub growing in temperate climate. A distinct storeyed pattern was observed in two-year-old stems, despite the presence of tall rays. The heterogeneous nature of storeys was revealed by the analysis of i) the number of fusiform initials forming storeys or groups of packets; and ii) the frequency of anticlinal divisions in the examined years of cambial activity and the calculation of the relative increase of the cambial circumference. The results are discussed on the basis of the recent hypothesis of intrusive growth of fusiform initial, occurring between the tangential walls of its neighbouring initial and its closest derivative.
\end{abstract}

Key words: vascular cambium, fusiform initials, rays, intrusive growth

\section{INTRODUCTION}

Secondary xylem (wood) is one of the most valuable natural resources and numerous observations concerning the development of wood have been described recently, but still they explain mostly the molecular mechanism of wood formation, usually not taking into consideration the cambium, that is, the tissue which is the origin of each layer of wood. Knowledge of the mechanisms of initial cambial rearrangement is still inefficient and understanding of this elusive tissue, as it was named by Sch mid (1976), seems to be essential for elucidating the mechanism of wood formation. The cambium consists of two types of cells: fusiform initials, whose derivatives form the longitudinal (axial) transport system, and ray initials, whose derivatives form the radial transport system rays (Wodzicki and Brown, 1973; Ajmal et al. 1986). Regarding the arrangement of fusiform and ray initials, there have been distinguished three major patterns of cambia: non-storeyed, storeyed and double-storeyed (R e c ord, 1919; C u mbi e, 1963, 1967; B a n n a n, 1968). The formation of storeys is frequently described as the result of radial longitudinal divisions (RLD) (C u m b i e, 1984; A j m a l et al. 1986; C a r lquis t, 1988), which means that storeys are derived by successive RLDs from a single procambial cell (homogenous storeys). The first observations of intrusive growth of fusiform initials in the storeyed cambium led to the conclusion that the storeyed pattern is maintained despite this phenomenon $(\mathrm{Z}$ a g ó $\mathrm{r}$ $\mathrm{ska-Marek,1984).} \mathrm{Examination} \mathrm{of} \mathrm{a} \mathrm{climbing}$ plant (Wisteria floribunda) revealed the heterogeneous nature of storeys, as a result of coordinated intrusive growth of the whole packets of fusiform initials (K o j s et al. 2004). This research will compare the storeyed cambium formation of shrub-like species with their observations.

The pattern of cambium is probably an effect of adaptation to specific environment conditions (K o j s et al. 2003; I q b a 1 et al. 2005); sometimes specimens of the same species form a storeyed or double storeyed pattern only when growing in windless conditions, like in dense forests (I q b a l et al. 2005). The pattern of cambial initials influences the properties of wood, e.g. the storeyed and double storeyed cambium is related to the formation of wavy or interlocked grain in wood respectively. Interlocked grain improves the mechanical strength of wood and allows the intensive longitudinal growth of trees to secure their access to light, which is essential in tropical rain forests ( $\mathrm{Iq}$ b a l et al. 2005). The double storeyed cambium and interlocked grain in wood are typical for tropical species which dominate (over $80 \%$ ) in the emergent layer of the tropical rain forest (K o j s et al. 2003). On the other hand, spiral 
grain in wood, which has been described for numerous trees of temperate climate, is more typical for the environment with prevailing winds. The occurrence of spiral grain improves security of longitudinal transport (K u b l e r , 1991) and also the mechanical strength of stems (S k a ter and K u č e r a, 1997, 2000), but reduces the commercial value of wood (North cott, 1965).

The aim of this work is to examine the process of storey formation in concordance with the new concept of cambial rearrangement and to determine the homogeneous or heterogeneous nature of storeys in Laburnum anagyroides. The understanding of the formation of the storeyed pattern and its significance for features of wood seem to be essential for improving the value of wood produced, therefore the examination of cambial initials rearrangement should not be neglected.

\section{MATERIALS AND METHODS}

Samples were collected in the middle of May 2005 , so in the peak of cambial activity, from young stems (1- and 2-year-old) and from mature stems (about 20-year-old) of a single specimen of Laburnum anagyroides Medik. (Fabaceae), a decorative shrub growing in a copse in Mikołów (Poland). This species was chosen due the rapid formation of the storeyed pattern of cambial initials, which often occurs in the first few years of cambial activity. Samples of 1- and 2-year-old cambia were prepared by cutting the young stems (5 pcs for each year of cambial activity) transversally into discs (approximately 20 pcs for each year of cambial activity) about $2 \mathrm{~mm}$ thick (in the axial direction) and then by dividing the discs radially into 4 or 8 equal pieces. Samples of 20-year-old cambium were prepared by cutting a stem segment, including the phloem and xylem, and then by dividing it into small samples; the dimensions of the samples were about $2 \mathrm{~mm}$ in circumferential direction, $3 \mathrm{~mm}$ in radial direction and $3 \mathrm{~mm}$ in axial direction. Next, the samples were fixed in $3 \%$ glutaraldehyde in phosphate buffer, dehydrated in acetone and propylene oxide, mounted in Epon 812 (Shell Chemical Co., USA), and cut into $3 \mu \mathrm{m}$ thick tangential or transverse sections (M e e k, 1976) in long series (at least 50 sections each). The sections were stained with Schiff's reagent and toluidine blue, and mounted on glass slides in euparal (W ł o c h and P o ła p, 1994) for examination under an Olympus microscope with plain apochromatic lenses. The figures were prepared using Corel Draw X3 software.

In tangential sections, the length of fusiform initials was measured using an ocular with a scale for random 25 initials observed in 2 different samples, thus a total of 50 initials for each year of cambial activity. On the basis of the length of the shortest and the longest fusiform initial, six ranges of length were determined and the number of fusiform initials belonging to those ranges was counted for each examined year of cambial activity. The mean diameter of the cambial cylinder was measured, the number of fusiform initials forming packets was counted and the structure of rays was examined (on at least two samples, for a total of 50 rays) for each year of cambial activity. The width of rays was estimated by counting the individual rays' initials in the widest area (seriate rays), and their height was estimated by counting the number of storeys they overcrossed. The percentage frequency of anticlinal divisions was estimated for each year of cambial activity, by counting the number of anticlinal divisions noticed in transverse sections for 400 radial rows. The relative increase of the cambial cylinder's circumference was calculated between the 1st and 2nd year of cambial activity, using the formula $\mathrm{d}=\mathrm{L} / \mathrm{L} * 100 \%\left(\mathrm{~L}_{2}-\mathrm{L}_{1} / \mathrm{L}_{1} * 100 \%\right)$, and also estimated in annual periods between 2- and 20-year-old cambia, assuming that the radius increment was constant (2.5 mm per year). Such a rate of radial increment in 20 years should increase the cambial radius to $25.6 \mathrm{~mm}$, thus similar to the actually measured one.

\section{RESULTS}

\section{A comparison of the ray patterns}

The rays in the examined samples of Laburnum anagyroides stems did not reveal the storeyed pattern. There were observed diversified rays, either short, less than $200 \mu \mathrm{m}$ in height, consisting of several individual ray initials (even one or two only), or tall, much more than $500 \mu \mathrm{m}$ in height. In the 1-year-old cambium, most of the rays were uniseriate and biseriate, rarely triseriate, either short or tall (even exceeding $1 \mathrm{~mm}$ in height), whereas seldom the multiseriate rays were rather short (Fig. 1). In the 2-year-old cambium, the ray width did not change significantly (Table 1), although triseriate or multiseriate rays occurred more frequently and varied in height: from short ones, located within the limits of one storey, to medium ones, occupying up to 6 storeys. The rays in the mature (20-year-old) cambium varied, as there were uniseriate, biseriate or seldom triseriate rays (the latter ones were always short and located within the limits of one storey), whereas the multiseriate rays were from short ones, even within the limits of one storey, to very tall ones, crossing up to 10 storeys. The width of multiseriate rays increased significantly from juvenile (1- and 2-year-old cambium) to mature cambium, even up 9 ray initials in the widest area (Fig. 1).

The height of rays significantly decreased temporally between the 1st and 2 nd year of cambial activity, whereas between the 1st and 20th year the change is insignificant (Table 2). The tallest rays crossed even 10 or 12 storeys in the mature or 1-year-old cambium, 
respectively, whereas in the 2-year-old cambium they crossed up to 6 storeys. However, in the mature cambium the percentage of short rays decreased and there frequently occurred very tall, multiseriate rays (Fig. 1).

\section{A comparison of the patterns of fusiform initials}

A tendency towards storeyedness was distinct in the first two years of cambial activity of L. anagyroides, despite the presence of tall rays (Fig. 2). In the 1-year-old cambium, regular storeys could not be distinguished and fusiform initials were arranged in a mosaic of packets, usually consisting of 2 to 4 cells (Table 3 ). Such packets may be homogeneous, probably originated via longitudinal anticlinal divisions, but the actual nature of packets was not examined in this research. In the 2-year-old cambium the number of fusiform initials in packets increased and the packets were frequently arranged in similar locations on two sides of the tall rays, thus two or more packets constituted one common storey. The boundaries of such storeys were often slanted, deviating from the typical transverse pattern. The mature cambium (20-year-old) presented a regular storeyed arrangement, though the actual number of fusiform initials forming the storeys was difficult to estimate, because the storeys frequently exceeded the size of the sections. The location of storeys was frequently similar on both sides of the tall multiseriate rays.

\section{The change in the length of fusiform initials}

A comparison of the mean length of fusiform initials in the examined years of cambial activity re- vealed a significant increase $(5 \%)$ between the 1 st and 2nd year of cambial activity, followed by a significant decrease (up to $88 \%$ of the initial value) in the mature cambium (Table 4). In the 1-year-old cambium the range of length of fusiform initials was the most diverse (Fig. 3). In the 2-year-old cambium most of fusiform initials (over 30\%) were included in the range 211-240 $\mu \mathrm{m}$; no shortest initials were observed but several very long initials occurred. In the mature cambium, the length of fusiform initials was the most uniform, as the majority of cells (60\%) were included in the range 181-210 $\mu \mathrm{m}$. Both the shortest and longest initials were absent. In all examined years, the mean length of fusiform initials was included in the range with the maximum number of initials.

\section{The frequency of anticlinal divisions of fusiform initials}

The frequency of anticlinal divisions decreased from $5 \%$ to $1 \%$ between the 1 st and 2 nd year of cambial activity. In the mature cambium, there occurred only 1 anticlinal division per 400 radial rows of fusiform cells $(0.25 \%)$. The relative increase in the cambial cylinder diameter (d) between the first year of its activity (cambial circumference $\mathrm{L}_{1}=10.7 \mathrm{~mm}$ ) and the second year $\left(\mathrm{L}_{2}=20 \mathrm{~mm}\right)$ was equal to $86.7 \%$. The radius of the cylinder of mature cambium was about $24.5 \mathrm{~mm}\left(\mathrm{~L}_{20}=154 \mathrm{~mm}\right)$. The decrease in the frequency of anticlinal divisions corroborates with the decrease in the relative increase in the cambial circumference (Fig. 4).

Table 1

Statistical analysis of ray width in the examined years of cambial activity in Laburnum anagyroides.

The t-Student test for independent groups. P value 0.05

\begin{tabular}{lccc}
\hline \multirow{2}{*}{ Parameter } & \multicolumn{2}{c}{ Analysis of ray width in the examined years of cambial activity } \\
\cline { 2 - 4 } & Year 1 & Year 2 & Year 20 \\
\hline Number of rays & 50 & 50 & 50 \\
Mean & 1.8 & 2.2 & 4.84 \\
Standard deviation & 0.989743 & 1.160577 & 3.019393 \\
-95\% CI for group's mean & 1.518718 & 1.870168 & 3.981898 \\
+95\% CI for group's mean & 2.081282 & 2.529832 & 5.698102 \\
\hline & Comparison of ray width between the examined years of cambial activity \\
\cline { 2 - 4 } & Year 1 and 2 & Year 2 and 20 & Year 1 and 20 \\
\hline Mean of differences & -0.4 & -2.64 & -3.04 \\
-95\% CI for mean of differences & -0.828069 & -3.547823 & -3.702059 \\
+95\% CI for mean of differences & 0.028069 & -1.732177 & -2.377941 \\
Standard error of mean of differences & 0.21571 & 0.457464 & 0.329452 \\
Common standard deviation & 1.078548 & 2.287321 & 2.329579 \\
t statistic & -1.854345 & -5.770944 & -9.227438 \\
Number of degrees of freedom & 98 & 98 & 98 \\
Bilateral p value & 0.066697 & $<0.000001$ & $<0.000001$ \\
\hline
\end{tabular}


Table 2.

Statistical analysis of ray height in the examined years of cambial activity in Laburnum anagyroides.

The t-Student test for independent groups. P value 0.05

\begin{tabular}{lccc}
\hline \multirow{2}{*}{ Parameter } & \multicolumn{2}{c}{ Analysis of ray height in the examined years of cambial activity } \\
\cline { 2 - 4 } & Year 1 & Year 2 & Year 20 \\
\hline Number of rays & 50 & 50 & 50 \\
Mean & 2.86 & 1.9 & 2.88 \\
Standard deviation & 2.784872 & 1.373956 & 2.446489 \\
-95\% CI for group's mean & 2.068548 & 1.509526 & 2.184716 \\
+95\% CI for group's mean & 3.651452 & 2.290474 & 3.575284 \\
\hline$\quad$ Parameter & Comparison of ray height between the examined years of cambial activity \\
\cline { 2 - 4 } & Year 1 and 2 & Year 2 and 20 & Year 1 and 20 \\
\hline Mean of differences & 0.96 & -0.98 & -0.02 \\
-95\% CI for mean of differences & 0.088493 & -1.767464 & -1.060316 \\
+95\% CI for mean of differences & 1.831507 & -0.192536 & 1.020316 \\
Standard error of mean of differences & 0.439164 & 0.396814 & 0.524229 \\
Common standard deviation & 2.195822 & 1.984069 & 2.621146 \\
t statistic & 2.18597 & -2.469672 & -0.038151 \\
Number of degrees of freedom & 98 & 98 & 98 \\
Bilateral p value & 0.031199 & 0.015253 & 0.969645 \\
\hline
\end{tabular}

Table 3 .

Variation in the number of cells forming packets or storeys between the first and second year of cambial activity of L. anagyroides

\begin{tabular}{cccccc}
\hline \multirow{2}{*}{$\begin{array}{c}\text { Year of cambial } \\
\text { activity }\end{array}$} & \multicolumn{2}{c}{ Average number of fusiform initials } & \multicolumn{2}{c}{ Maximum number of fusiform initials } & Cambial diameter [mm] \\
\cline { 2 - 5 } & In packet & In storey & In packet & In storey & \\
\hline Year 1 & $2-4$ & $2-4$ & 6 & 6 & 10,7 \\
Year 2 & $6-10$ & $15-17$ & 12 & 23 & 20 \\
\hline
\end{tabular}

Table 4.

Statistical analysis of the length of fusiform initials in the examined years of cambial activity.

The t-Student test for independent groups. P value 0.05

\begin{tabular}{|c|c|c|c|}
\hline \multirow{2}{*}{ Parameter } & \multicolumn{3}{|c|}{ Analysis of fusiform initial length in the examined years of cambial activity } \\
\hline & Year 1 & Year 2 & Year 20 \\
\hline Number of rays & 50 & 50 & 50 \\
\hline Mean & 211.8 & 232.18 & 190.44 \\
\hline Standard deviation & 38.650184 & 27.693431 & 17.128756 \\
\hline$-95 \%$ CI for group's mean & 200.815739 & 224.309614 & 185.572061 \\
\hline$+95 \%$ CI for group's mean & 222.784261 & 240.050386 & 195.307939 \\
\hline \multirow[t]{2}{*}{ Parameter } & \multicolumn{3}{|c|}{$\begin{array}{l}\text { Comparison of fusiform initial length between the examined years of } \\
\text { cambial activity of } L \text {. anagyroides }\end{array}$} \\
\hline & Year 1 and 2 & Year 2 and 20 & Year 1 and 20 \\
\hline Mean of differences & -20.38 & 41.74 & 21.36 \\
\hline$-95 \%$ CI for mean of differences & -33.724014 & 32.601445 & 9.495503 \\
\hline$+95 \% \mathrm{CI}$ for mean of differences & -7.035986 & 50.878555 & 33.224497 \\
\hline Standard error of mean of differences & 6.724229 & 4.605042 & 5.97868 \\
\hline Common standard deviation & 33.621146 & 23.025208 & 29.893402 \\
\hline t statistic & -3.030831 & 9.063979 & 3.572695 \\
\hline Number of degrees of freedom & 98 & 98 & 98 \\
\hline Bilateral $\mathrm{p}$ value & 0.00312 & $<0.000001$ & 0.00055 \\
\hline
\end{tabular}




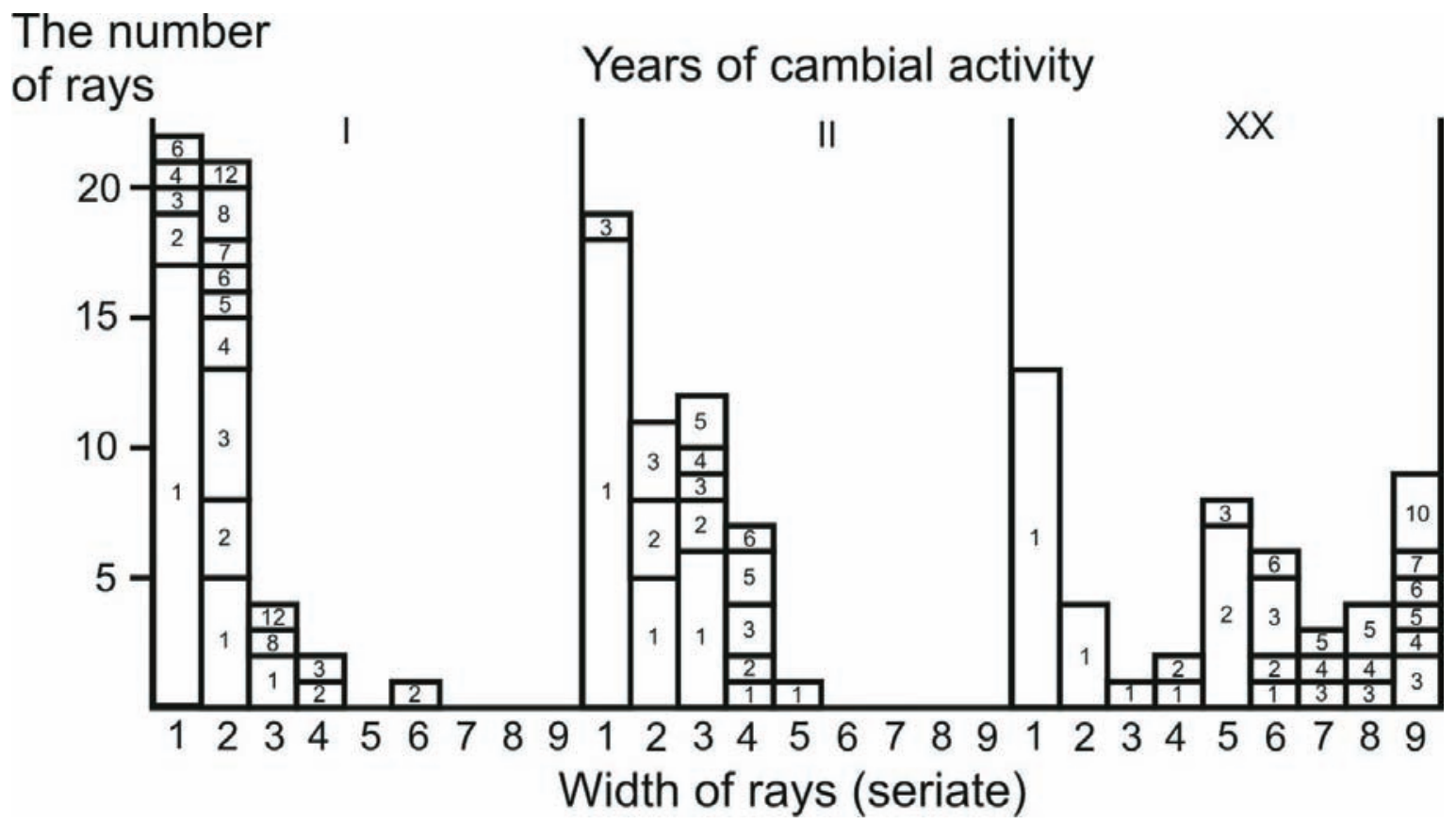

Fig. 1. The diagram presents the diversity of rays in the examined years $(1,2,20)$ of cambial activity of Laburnum anagyroides. Each column (1-9) represents an exact width of the ray. The height of each column represents the number of rays of this width, according to the vertical axis (marked as "The number of rays"). The columns are divided into rectangles, marked with the number inside them (1-12) indicating the height of rays. The height of rectangles corresponds with the number of rays of each type (as regards both the width and height) observed in the examined year of cambial activity.

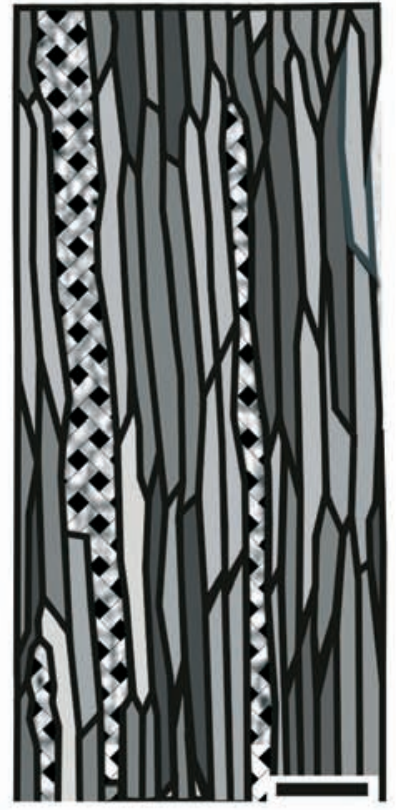

I

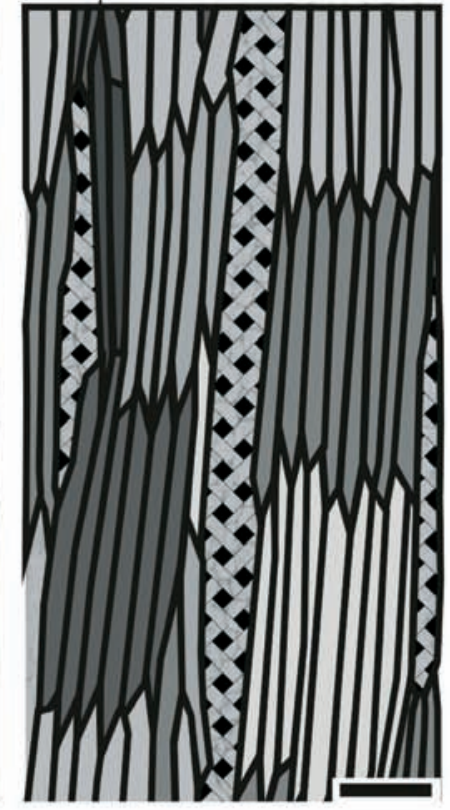

II

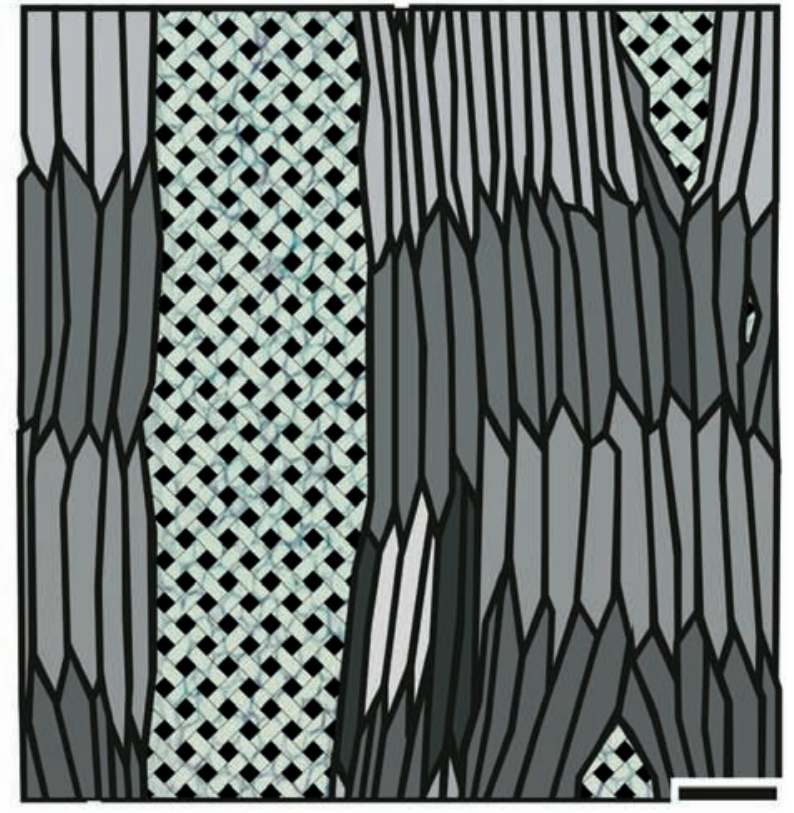

$\mathrm{XX}$

Years of cambial activity

Fig. 2. Comparison of the arrangement of cambial initials, typical for the examined years of cambial activity of Laburnum anagyroides. The homogeneous packets or groups of packets forming one heterogeneous storey are marked with the same degree of gray. Rays are filled with a crisscross pattern. 


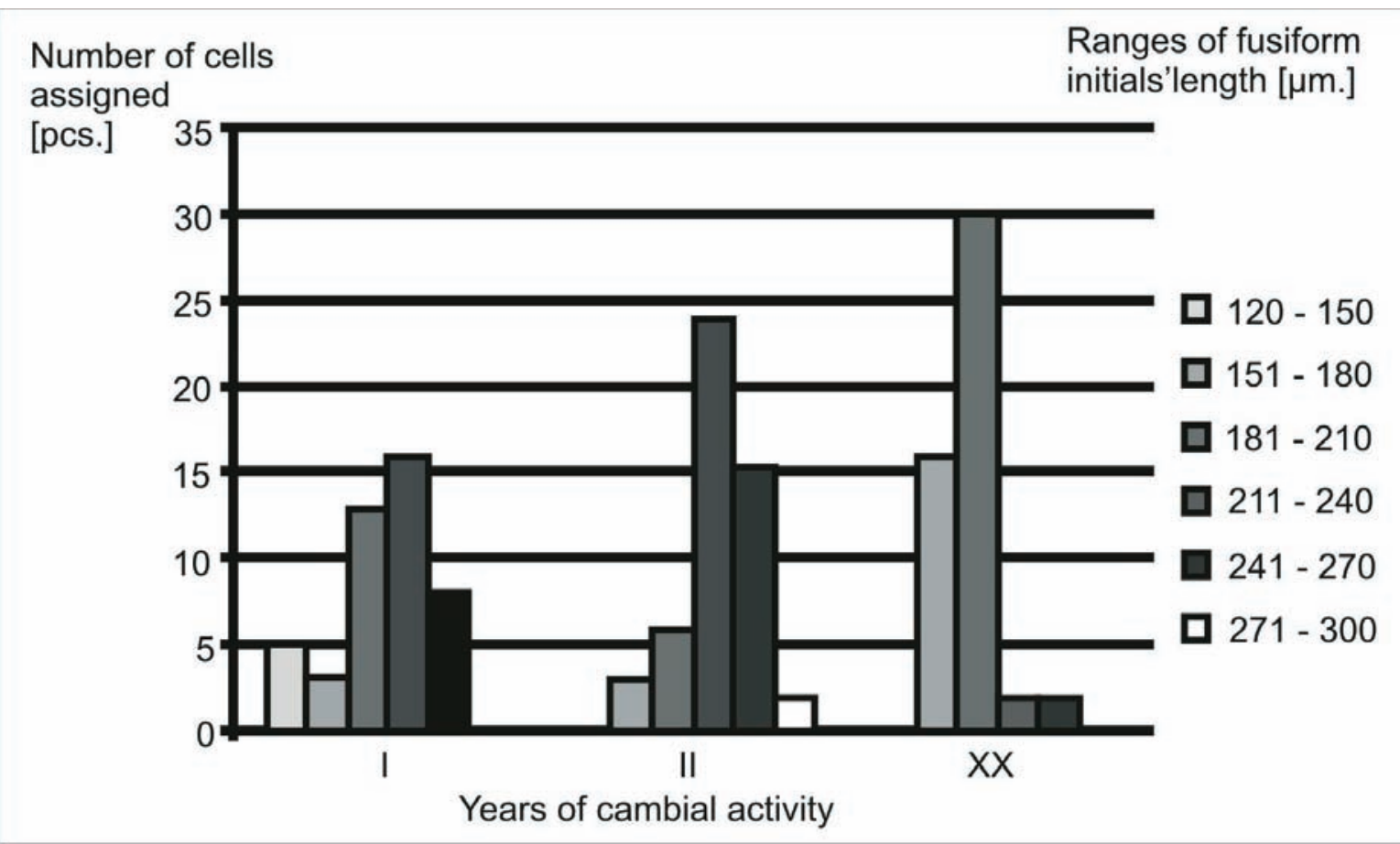

Fig. 3. Variation in the length of fusiform initials observed in the examined years of activity of Laburnum anagyroides cambium. Each column represents one range of fusiform initial length, marked with one degree of gray. The height of each column represents the number of fusiform initials assigned to this range of length, according to the vertical axis (marked as "The number of cells assigned").

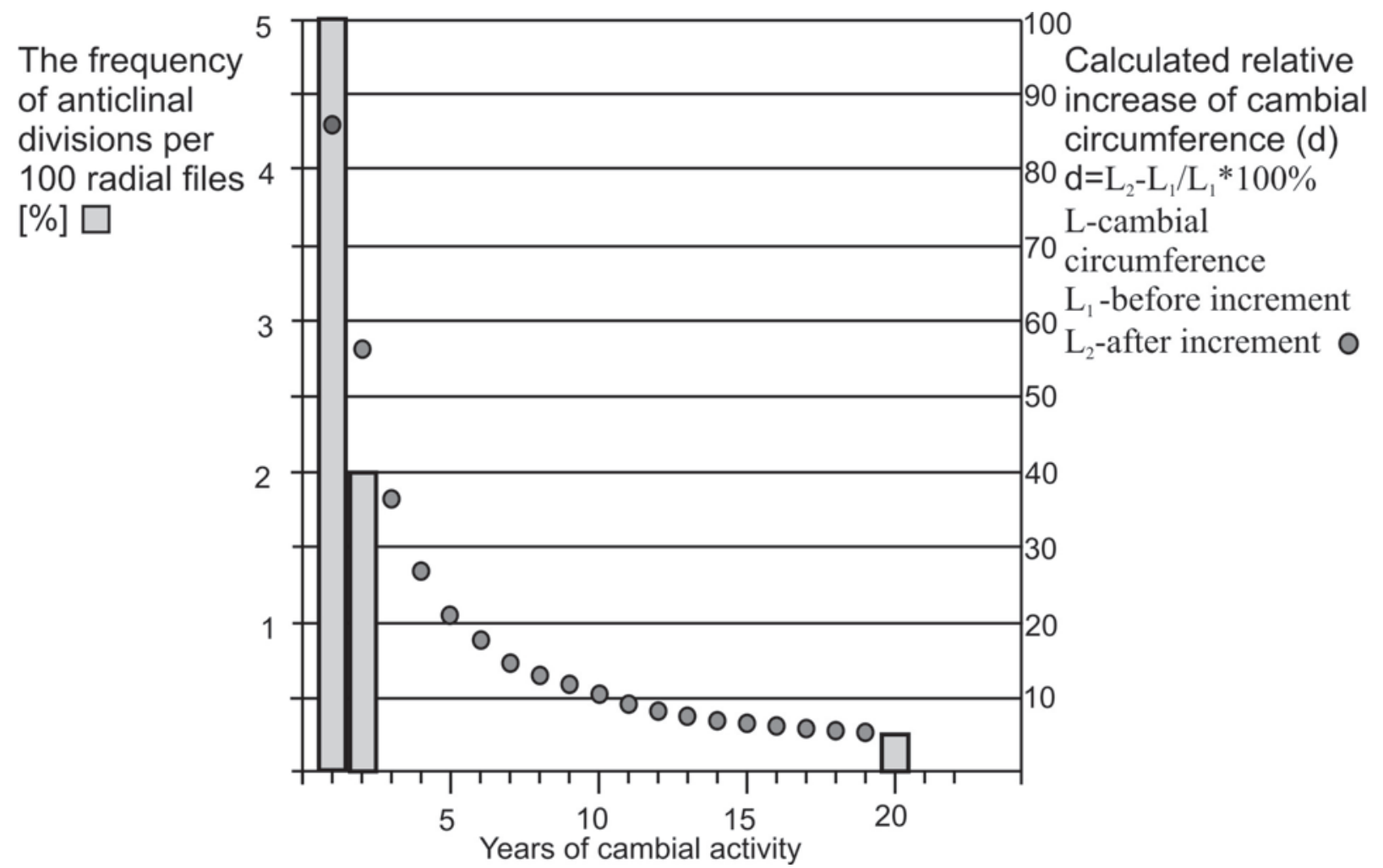

Fig. 4. Comparison of the frequency of anticlinal divisions calculated for the examined years of cambial activity of Laburnum anagyroides and the annual relative increase of the cambial circumference from 1- to 20-year-old cambium. 


\section{DISCUSSION}

In the cambium of $L$. anagyroides, the tendency towards storeyed arrangement was distinct already in the first two years of cambial activity. The storeyed cambium develops from non-storeyed procambium in time, which lasts even several decades (Record, 1919). It has been usually described as a result of radial (anticlinal) longitudinal divisions (RLD) of fusiform initials, not followed by the intrusive growth of initials (C u m b i e, 1984; A j mal et al. 1986; C a r lqu is t, 1988; S t e e v e s and S u s s e x, 1989). The formation of homogenous packets, resulting from RLD, is undoubtedly involved in storey formation; however, the hypothesis of heterogeneous storeys described by Kojs et al. (2004) suggests that RLDs solely are insufficient to explain the formation of storeys. The repeated RLDs of fusiform initials lead to the formation of a mosaic of homogeneous packets, which has been presented by K o j s et al. (2002,2004). A similar mosaic of packets was observed in this work. Further RLDs of fusiform initials can widen the packets, but common, regular storeys apparently cannot be formed without considering the adjustment of the location of packets on the cambial surface. The location of the storeys' boundaries was maintained on both sides of very tall rays already in the 2 nd year of cambial activity. Such rays are obviously obstacles for the expansion of homogeneous storeys, hence these storeys are almost certainly consisted of heterogeneous packets which had adjusted their location with respect to the neighbouring packets.

The rapid formation of storeys in the first two years of cambial activity is frequent in the tropics and it is typical for the highest trees of tropical rain forests, mostly in the families Fabaceae, Sterculiaceae and Meliaceae (R e c or d, 1919; C a r lqu is t, 1988; K o j s et al. 2004; I q b a l et al. 2005), although it is sparse in the temperate climate (rather found in some introduced species, like Laburnum anagyroides or Wisteria floribunda) and cannot be explained only by the occurrence of RLDs. The formation of a homogeneous packet from a single initial must be related to the adequate number of RLDs, hence also an adequate increase of cambial circumference, e.g. the formation of a packet consisting of 8 initials due to RLD is possible in 3 generations: the first division results in 2 sister initials, the next RLD of those two initials results in 4 sister initials, and the third generation - in 8 sister initials. In the same time, the circumferential dimension of this packet (assuming that the dimensions of initials are maintained) should increase to $800 \%$. In the 1-year-old cambium of $L$. anagyroides, the average packets consisted of 2-4 initials, whereas in the 2-yearold cambium of 6-10 initials. Such an increase in packets should be associated with a 150\%-200\% relative increase in the cambial circumference, respectively, yet actually it was only $86.7 \%$. Assuming that the formation of packets results exclusively from RLDs, in such a situation we should expect packets to consist of about 4-7 fusiform initials.

Whereas fusiform initials of the non-storeyed cambium increase their length rather gradually (S te e ve s and S u s sex, 1989), in the cambium of $L$. anagyroides the mean length of fusiform initials decreased after a temporary increase, which corroborates with the observations of B u t t e r f i e ld (1972), A j $\mathrm{m}$ a $\mathrm{l}$ et al. (1986), and $\mathrm{Ko} \mathrm{j} \mathrm{s}$ et al. (2004). This decrement seems to be typical for storey formation, possibly related to the intensive rearrangement of the location of whole packets. Together with the decrease in the mean length of fusiform initials, the height of whole storeys also decreased, which means that the number of successive storeys in the same area of cambium increased (Fig. 2). In the mature cambium of L. anagyroides, the fusiform initials were rather short (the mean length was equal to $190.5 \mu \mathrm{m}$, Table 4), compared to other species with storeyed cambium. G h o u s e et al. (1980) noted that usually the mean length of fusiform initials was 186 to $649 \mu \mathrm{m}$, while according to Larson (1994) 138 to $535 \mu \mathrm{m}$. In the mature cambium of W. floribunda, most fusiform cells (over 40\%) were about $180 \mu \mathrm{m}$ long (K o j s et al. 2004).

Kitin et al. (1999) compared two different methods of measurement of initial length in the non-storeyed cambium: 1) after maceration; and 2) in tangential sections. In the former method, the mean length of fusiform initials was included in the length range with the maximum number of fusiform initials assigned, whereas in the latter method it was significantly smaller. The authors interpreted this as a result of imprecise measurement in tangential sections and assessed that the method of measurement after maceration was more precise. The fusiform initials in the nonstoreyed cambium are more diverse in length and they are generally much longer than in the storeyed cambium, which may cause the measurement of individual cells to be difficult. The storeyed cambium is characterised by rather short fusiform initials and the measurement in tangential sections seems to be a sufficient method (B u t terfield, 1973; A j mal et al. 1986). In the present study, the mean length of fusiform initials, measured in tangential sections, was included in the range with the maximum number of fusiform initials assigned. The analysis of the number of fusiform initials assigned to the determined length ranges reveals that the diversity in the length of fusiform initials decreases during the formation of the regular storeyed pattern, which is consistent with the observations on W. floribunda (K o j s et al. 2004).

The occurrence of intrusive growth of cambial initials was at first described for the non-storeyed 
cambium as occurring between the radial walls of neighbouring initials, usually following oblique anticlinal divisions which resulted in the increase of the cambial circumference (B an n an, 1967, 1968; Cumbie, $1967 ;$ Krawczyszyn, $1973 ; 1977$; Catesson, 1984; Savidge and Farrar, 1984; $\mathrm{W} \nmid \mathrm{och}$, 1985). The difficulty of explaining the intensive rearrangement of cambial initials exclusively by intrusive growth was emphasized (B a n n a n, 1964, 1966; Harris, 1973; Savidge and Farrar, 1984). This hypothesis of intrusive growth also did not explain the intense rearrangement of initials arranged in the storeyed pattern, occurring rather in old stems where the relative increase of the cambial circumference was almost nil. On the basis this hypothesis, the increase of the cambial circumference was commonly explained in a different way for the storeyed cambium (due to RLDs and symplastic growth) and for the nonstoreyed cambium (due to oblique anticlinal divisions and intrusive growth) (C u mbie, 1967; B a n n a n and B in d ra, 1970; K r a w c z y s z y n, 1977; S a v idge and Farrar, 1984; W ł och, 1985). It should be pointed out that these two patterns of cambial initial arrangement are not discrete, since the storeyed cambium develops from the non-storeyed cambium in time, some individuals of a given species form storeyed cambium, while others do not (depending e.g. on environmental conditions, as in Tilia sp.). In one specimen in older branches the cambium may be storeyed, while in younger branches it is still non-storeyed, or even storeyed packets of cells may occur right next to the non-storeyed area of cambium, like in the case of intermediate cambium (e.g. F. excelsior) described by K r a w c z y s z y n (1977). Would it be that one mechanism of tissue growth occurs in one cell, whereas in the neighbouring cell it is different? This seems to be very improbable.

The latter hypothesis assumes that an initial, growing intrusively, grows between the tangential walls of the neighbouring initial and its closest derivative, and takes part in some kind of competition between segments of two initials for the same area of the cambial circumference called the 'initial surface' (W ł o c h , 1981; K o j s et al. 2004). One of those initials wins this competition and remains on the initial surface, while the other one loses this competition and its part is pushed away from the initial surface either to the phloem or xylem side, which is described as elimination. The next periclinal division of the declining initial is unequal and results in two cells: one cell (shortened) keeps the status of the initial, while the other is a derivative on the phloem or xylem side. The intrusive growth of one initial is inseparably associated with at least partial elimination of other initial/initials from the initial surface, thus neither of them influences the cambial circumference ( $\mathrm{J}$ u r a et al. 2006; W f o c h et al. 2009; Wilczek et al. 2011). The recent hypothesis of intrusive growth occurring between the tangential walls precisely separates the mechanism of cambial circumference increase, as a result of anticlinal divisions and symplastic growth, and the mechanism of rearrangement of cambial initials, predominantly as a result of intrusive growth (balanced with eliminations). Both mechanisms occur independently and are common features of the cambium, regardless of its pattern.

Two types of rearrangement of fusiform initials were described: i) vertical, changing the location of initials (or whole packets of initials) and taking part in storey formation; ii) horizontal, changing the orientation and inclination of fusiform initials ( $\mathrm{Koj} \mathrm{s}$ et al. 2002, 2004). The horizontal rearrangement of cambial initials is recorded in the successive layers of cambial derivatives, displayed as grain in wood. Whereas in temperate trees spiral or wavy grain occurs in wood, in tropical rainforests species presenting interlocked grain in wood are frequent, being unusually numerous in the canopy and emergent layers of the forest (K oj s et al. 2003; Iq bal et al. 2005). The species with wavy or interlocked grain in wood usually exhibit the storeyed or double-storeyed pattern of cambium, respectively (K o j s et al. 2003). The double-storeyed cambium has been described as 'functional storeyed arrangement' (K o j s et al. 2002), since it apparently allows for the most intense and synchronized rearrangement of cambial initials due to intrusive growth (I q b a 1 et al. 2005), regardless of the lack of oblique anticlinal divisions (B u t terfie ld, 1972; K rawczyszyn, 1977; Ajmal et al. 1986). This is contrary to the general opinion that in the storeyed cambium intrusive growth is insignificant ( $\mathrm{Hej} \mathrm{now} \mathrm{icz,}$ 1973). In the juvenile cambium of L. anagyroides, tall, uniseriate or biseriate rays frequently occurred, whereas in the mature cambium narrow rays were only short and located in one storey, but tall, wide rays occurred frequently. This phenomenon may be explained in two ways: by the widening of tall narrow rays and / or by their splitting to several short rays. Considering the regular storeyed pattern of this cambium, the horizontal rearrangement may be the reason of frequent splitting of rays, and apparently narrow rays seem to be more susceptible to splitting than wide ones.

Although it may seem that the exact location of intrusive growth is a marginal problem, two hypotheses described here explain the increase of the cambial circumference and rearrangement of cambial initials as the result of entire different mechanisms. Despite all doubts and vagueness of the former hypothesis, it has been widely described in articles and textbooks and is still exploited in most of works concerning the cam- 
bium, even if not expressed directly. The formation of the storeyed pattern is also a much more complex process than it was believed and the mechanisms controlling this process are still to be investigated. The main aim of this work is to present the process of formation of heterogeneous storeys on the example of L. anagyroides, on the basis the recent hypothesis of intrusive growth, as a mechanism of rearrangement of cambial initials, but not as a mechanism of cambial circumference increase.

\section{CONCLUSIONS}

The storeyed arrangement of cambium of $L$. anagyroides is distinct in young, even 2-year-old stems, regardless of the presence of tall, often multiseriate rays. The occurrence of RLDs in fusiform initials in L. anagyroides results in the formation of a mosaic of homogeneous packets, but the occurrence of RLDs cannot explain the formation of regular storeys, thus storeys are heterogeneous (composed of several homogeneous packets). The possible mechanism of storey formation is the vertical rearrangement of the location of packets. The formation of heterogeneous storeys is associated with the unification of length of fusiform initials and also their shortening. The recent observations are consistent with the hypothesis of intrusive growth of cambial initials occurring between the tangential walls of neighbouring initials and their closest derivatives.

\section{Acknowledgements}

This research has been funded by Botanical Garden of the Center for Biological Diversity Conservation in Powsin.

I wish to thank Dr habil. Wiesław Włoch for his patronage of this research and Dr Paweł Kojs for his inspiring remarks and also to acknowledge the critical review of Prof. Weryszko-Chmielewska from the University of Life Sciences in Lublin and Prof. Anna Tomczyk from the Warsaw University of Life Sciences (SGGW).

\section{REFERENCES}

Ajmal S., Khan R., Iqbal M., 1986. Cambial structure of Holoptelea integrifolia PLANCH in relation to age. Flora, 178: 197-202.

B a n n a n M.W., 1964. Tracheid size and anticlinal divisions in the cambium of Pseudotsuga. Can. J. Bot. 42: 603631.

B a n nan M.W., 1966. Spiral grain and anticlinal divisions in the cambium of conifers. Can. J. Bot. 44: 1515-1530.

Bannan M.W., 1967. Anticlinal division and cell length in conifer cambium. For. Prod. J. 17 (6): 63-69.
B a n n a n M.W., 1968. Anticlinal divisions and the organization of the conifer cambium. Bot. Gaz. 129: 107-113.

Bannan M.W., Bindra M., 1970. Variations in cell length and frequency of anticlinal division in the vascular cambium throughout a white spruce tree. Can. J. Bot. 48: 1363- 1371.

Butterfield B.G., 1972. Developmental changes in the vascular cambium of Aschynomene hispida Willd. New Zeal. J. Bot. 10: 373-386.

Butterfield B.G., 1973. Variation in the size of fusiform cambial initials and vessel members in Hoheria angustifolia Raoul. New Zeal. J. Bot. 11: 391-410.

Carlquist S., 1988. Comparative wood anatomy. Berlin, Heidelberg, New York: Springer-Verlag

Cate s s on A.M., 1984. Cambial dynamics. Ann. Science Nat. Bot. 13 (6): 23-43.

Cumbie B.G., 1963. The vascular cambium and xylem development in Hibiscus lasiocarpus. Am. J. Bot. 50: 944-951.

Cumbie B.G., 1967. Developmental changes in the vascular cambium of Leitneria floridana. Am. J. Bot. 54: 414-424.

Cumbie B.G., 1984. Origin and development of the vascular cambium in Aeschynomene virginica. Bull. Torrey Bot. Club 111: 42-50.

Ghouse A.K.M, Khan M.I.H, Khan S., Khan A.H., 1980. Comparative Study on the Structure of Vascular Cambium in some Verbenaceae. India Phytomorphol. 30 (1): 32-40.

Harris J.M., 1973. Spiral grain and xylem polarity in radiata pine: microscopy of cambial reorientation. New Zeal. J. For. Science, 3: 363-378.

Hejnowicz Z., 1973. Anatomia rozwojowa drzew. Państwowe Wydawnictwo Naukowe. (in Polish)

Iqbal M., Kojs P., Włoch W., Szendera W., J u r a J ., 2005. Presence of storeyed cambium in trees of the tropical rain forests: an adaptative strategy. XVII Int. Bot. Congr. in Vienna, 2005.

Jura J., Kojs P., Iqbal M., SzymanowskaPułka J., Włoch W., 2006. Apical intrusive growth of cambial fusiform initials along the tangential walls of adjacent fusiform initials: evidence for a new concept. Aust. J. Bot. 54 (5): 493-504.

Kitin P.B., Funada R., Sano Y., Beeckman H., Ohtani J., 1999. Variations in the lengths of fusiform cambial cells and vessel elements in Kalopanax pictus. Ann. Bot. 84: 621-632.

Kojs P., Włoch W., Rusin A., 2004. Rearrangement of cells in storied cambium of Lonchocarpus sericeus (Poir.) DC. connected with formation of interlocked grain in the xylem. Trees, 18: 136-144.

Kojs P., Włoch W., Rusin A., Szendera W., Duda J., Jura J., Rusin T., 2002. Od niefunkcjonalnej do funkcjonalnej piętrowości kambium. Modele piętrowości. Bull. Bot. Gardens. 11: 93-104. (in Polish) 
Kojs P., Włoch W., Rusin A., Szendera W., 2003. Storeyed structure of cambium as an adaptive strategy to environmental conditions in trees forming canopy and the emergent layer oft he tropical rain forests. Bull. Bot. Gardens, 12:23-29.

Kojs P., Rusin A. Iqbal M., Włoch W., Jura J., 2004. Readjustments of cambial initials in Wisteria floribunda (Willd.) DC. For. development of storeyed structure. New Phytol. 163 (2): 287-297.

K rawczyszy n J., 1973. Domain pattern in the cambium of young Platanus stems. Acta Soc. Bot. Pol. 42: 637-648.

Krawczyszyn J., 1977. The transition form nonstoried to storied cambium in Fraxinus exelsior L. 1. The occurrence of radial anticlinal divisions. Can. J. Bot. 55: 3034-3041.

Kubler H., 1991. Function of spiral grain in trees. Trees, 5: 125-135.

Lars on P.R., 1994. The vascular cambium: development and structure. Berlin, Heidelberg, New York: SpringerVerlag.

Meek G.A., 1976. Practical electron microscopy for biologists. John Wiley \& Sons, London, New York, Sydney, Toronto.

Northcott P.L., 1965. The effects of spiral grain on the usefulness of wood. Proc IUFRO, Melbourne, 41(1): pp. 15.

Record S.J., 1919. Storied or tier-like structure in certain dicotyledonous woods. Bull. Torrey Bot. Club, 46: 253273.

Savidge R.A., Farrar J.L., 1984. Cellular adjustments in the vascular cambium leading to spiral grain formation in conifers. Can. J. Bot. 62: 2872-2879.

S c h m id R., 1976. The elusive cambium-another terminological contribution. IAWA 4: 51-59.

Skatter S., Kučera B ., 1997. Spiral grain - an adaptation of trees to withstand stem breakage caused by wind induced torsion. Holz Roh- Werkst, 55: 207-213.

Skatter S., Kučera B., 2000. Tree breakage from torsional wind loading due to crown asymmetry. For. Ecol. Manage, 135: 97-103.

Steeves T.A., Sus sex I.M., 1989. Patterns in plant development. $2^{\text {nd }}$ Ed. Cambridge Univ. Press.

Wilczek A., Jura-Morawiec J., Kojs P., Iqbal M., Włoch W., 2011. Correlation of intrusive growth of cambial initials to rearrangement of rays in the vascular cambium. IAWA J., 32 (3): 313-332.

W ł o ch W., 1981, Nonparallelism of cambium cells in neighbouring rows. Acta Soc. Bot. Pol. 50: 625-636.

Włoch W., 1985. Time-variable frequency of events in domains of Tilia cambium. Acta Soc. Bot. Pol. 54: 29-40.

W łoch W., Połap E., 1994. The intrusive growth of initial cells in re-arrangement of cells in cambium of Tilia cordata Mill. Acta Soc. Bot. Pol. 63: 109-116.

Włoch W., Jura-Morawiec J., Kojs P., Iqbal M., Krawczyszyn J., 2009. Does intrusive growth of fusiform initials really contribute to circumferential growth of vascular kambium? Can. J. Bot. 87: 1-10.

Wodzicki T.J., Brown C.L., 1973. Cellular differentiation of the cambium in the Pinaceae. Bot. Gaz. 134 (2): 139-146.

Zagórska-Marek B., 1984. Pseudotransverse divisions and intrusive elongation of fusiform initials in the storied cambium of Tilia. Can. J. Bot. 62: 20-27.

\section{Formowanie się heterogennej piętrowości kambium Laburnum anagyroides Medik}

\section{Streszczenie}

Badanie formowania piętrowości oraz struktury dojrzałego kambium Laburnum anagyroides, krzewu ozdobnego rosnącego w klimacie umiarkowanym Polski (Katowice) wykazały, że piętrowość powstaje w ciągu dwóch pierwszych lat aktywności kambium pomimo obecności wysokich, wielorzędowych promieni. Analizy: i) liczby inicjałów wrzecionowatych tworzących pakiety lub wspólne piętra po obu stronach wysokich, często wielorzędowych promieni oraz ii) częstotliwości podziałów antyklinalnych w badanych latach aktywności kambium w porównaniu do przyrostu względnego obwodu kambium wskazują na heterogenną naturę pięter. Wyniki zostały omówione w oparciu o założenia hipotezy wzrostu intruzywnego inicjałów kambium, jako zachodzącego pomiędzy ściany styczne sąsiednich inicjałów oraz ich najbliższych pochodnych. 